(2) Open Access Full Text Article

REVIEW

\title{
Long-term effectiveness and safety of sirolimus drug-eluting stents
}

This article was published in the following Dove Press journal:

Medical Devices: Evidence and Research

16 August 2011

Number of times this article has been viewed

\section{Mahesh Bikkina \\ Jayanth Koneru}

St Joseph Regional Medical Center, Paterson, Seton Hall University, NJ, USA
Correspondence: Mahesh Bikkina Seton Hall Cardiology Fellowship Program, St Joseph Regional Medical Center, 709 Main Street, Paterson, NJ 07503, USA

Tel + I 9737542300

Fax + I 9737542327

Email maheshbikkina@yahoo.com

\begin{abstract}
The root cause of coronary artery disease is atherosclerosis, ie, intraluminal narrowing (stenosis) of the arteries that supply blood to tissues of the heart. The introduction of the drug-eluting stent over the past decade has revolutionized the field of interventional cardiology. It is used extensively in clinical practice for the treatment of coronary artery disease. The first drug-eluting stent to receive US Food and Drug Administration approval was the sirolimus-eluting stent. Recently, two other stent analogs of sirolimus were approved, ie, the zotarolimus-eluting stent and the everolimus-eluting stent. However, concern has arisen in recent years about the long-term safety and efficacy of drug-eluting stents, due to the occurrence of late adverse clinical events, such as stent thrombosis. This review focuses on clinical studies that have been performed with the sirolimus-eluting stent or its analogs. We discuss the pharmacology, safety, and various therapeutic options that exist when choosing stents for coronary artery disease. Our aim is to provide a thorough review of the long-term efficacy and safety of sirolimus drug-eluting stents, and also to discuss currently approved and promising investigational drug-eluting stents, in an effort to provide insight into how these stents are currently evolving and generate further investigation in this area.
\end{abstract}

Keywords: drug-eluting stent, long-term safety, sirolimus

\section{Introduction}

In 1977, Andreas Grüntzig introduced percutaneous transluminal coronary angioplasty, whereby a catheter was introduced through a peripheral artery and a balloon expanded to dilate the narrowed segment of artery. ${ }^{1}$ Since then, the explosion in percutaneous techniques and research has been astonishing. In the mid-1980s, Dotter and Judkins were among the first to suggest using prosthetic devices inside arteries to maintain blood flow after dilation. ${ }^{2}$ In 1986, Puel and Sigwart implanted the first coronary stent in a human patient. ${ }^{3}$ This would eliminate two of the main problems associated with angioplasty, ie, elastic recoil and neointimal hyperplasia. ${ }^{4}$ Multiple trials have demonstrated the superiority of stents versus balloon angioplasty. Stents nonetheless remained vulnerable to restenosis, even though this occurred with less frequency than with balloon angioplasty.

To address the issue of restenosis, developers of drug-eluting stents were using the devices themselves as a platform for delivery of antiproliferative drugs by 2001. This drug delivery method involved applying high concentrations locally and directly at the target lesion, with minimal systemic side effects. Drug-eluting stents, as a group, are superior to bare metal stents in reducing the incidence of restenosis, intimal hyperplasia, and repeat interventions..$^{5}$ They have antiproliferative and antimigratory properties, 
which prevent restenosis via smooth muscle inhibition. ${ }^{6-8}$ The different drug mechanisms and delivery platforms have been found to have different clinical outcomes.

\section{Pharmacology}

The ideal drug-eluting stent should have three components:

- A design that allows for uniform scaffolding and drug distribution.

- A polymer that is biocompatible, and maintains and provides consistent controlled release of a therapeutic level of the drug into the tissue; the drug must not wash off during the most time-intensive procedures and must provide durability, ensuring drug retention during stent delivery and deployment (Figure 1).

- A drug that safely and effectively prevents neointimal hyperplasia while allowing natural healing to occur.

The Cypher $^{\circledR}$ is designed to be a closed-cell drug delivery platform. The closed-cell design ensures optimal drug delivery in two ways, ie, circumferentially via a consistent metal-to-artery ratio, and longitudinally via consistent uniform lesion coverage in the most tortuous vessels.

Sirolimus is the alternative name for rapamycin, a rarely used antibiotic. Sirolimus is highly lipophilic and has two mechanisms of action, ie, antiproliferation of the intima and reduction of inflammatory cell activity. The selectivity for proliferating cells and preferential targeting of smooth muscle cells occurs via target of rapamycin (TOR). It also has a cytostatic mode of action whereby it acts before the critical checkpoint in the G1 phase of the cell cycle. Sirolimus also has the ability to stop the proliferation of smooth muscle cells effectively. The mechanism of action is shown in Figures 2-5.

The typical dose of sirolimus in each Cypher stent is $140 \mu \mathrm{g} / \mathrm{cm}^{2}$. The high lipid solubility of sirolimus allows it to pass easily through cell membranes and contributes to

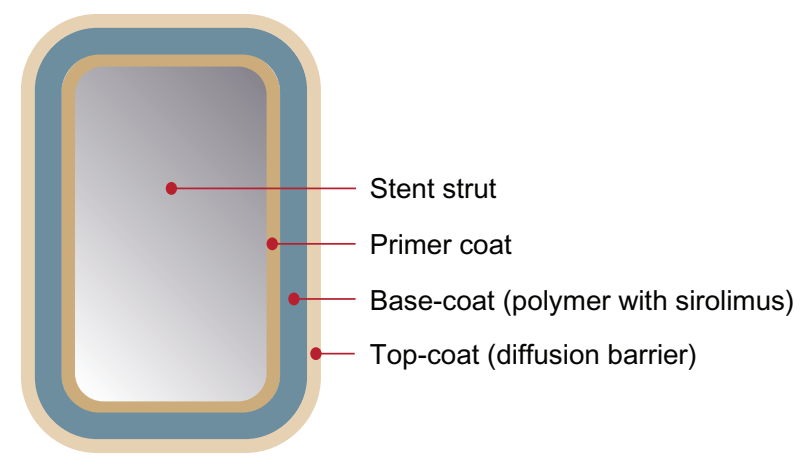

Figure I CYPHER ${ }^{\circledR}$ sirolimus-eluting coronary stent. (c) Cordis Corporation 2010.

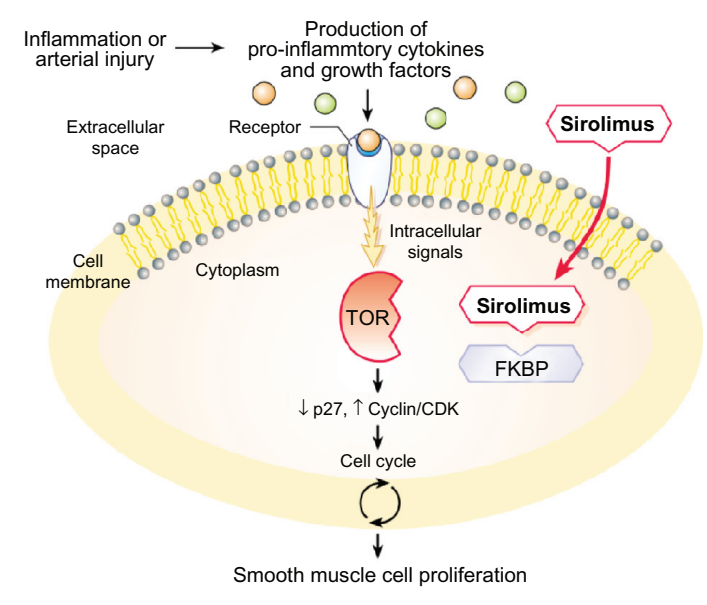

Figure 2 Diffusion of sirolimus into smooth muscle cells. (c) Cordis Corporation 2010.

Abbreviations: CDK, Cyclin-dependent kinose; FKBP, FK binding protein; TOR, Target of Rapomylin.

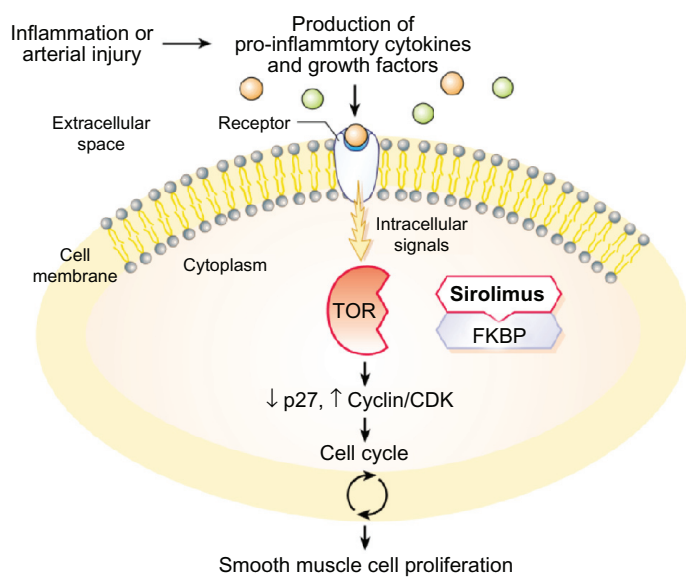

Figure 3 Sirolimus binds to FKBP to form a sirolimus-FKBP complex. (C) Cordis Corporation 2010.

Abbreviations: CDK, Cyclin-dependent kinose; FKBP, FK binding protein; TOR, Target of Rapomylin.

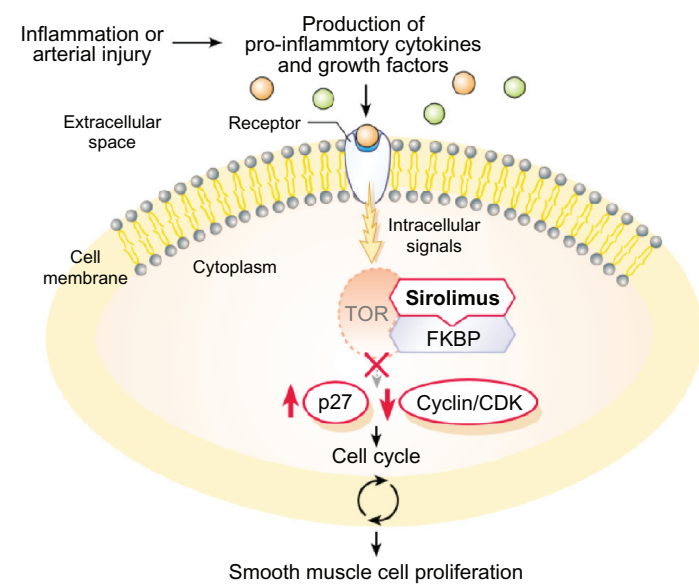

Figure 4 The sirolimus-FKBP complex binds to TOR, p27 levels increase, and cyclin/CDK is inhibited.

(C) Cordis Corporation 2010.

Abbreviations: CDK, Cyclin-dependent kinose; FKBP, FK binding protein; TOR, Target of Rapomylin. 


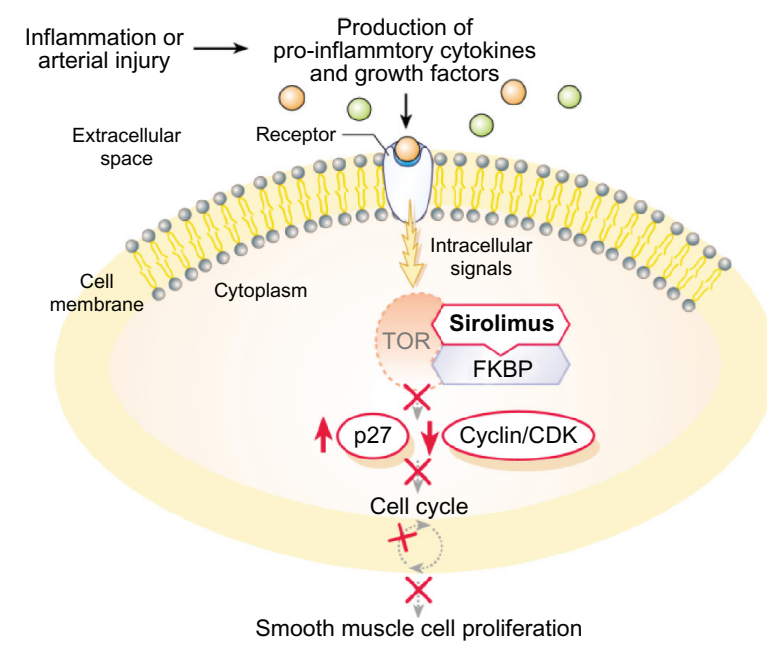

Figure 5 Elevated p27 levels inhibit cyclin/CDK activity, turning off the cell cycle in GI (at the GI checkpoint).

(C) Cordis Corporation 2010.

Abbreviations: CDK, Cyclin-dependent kinose; FKBP, FK binding protein; TOR, Target of Rapomylin.

its retention in arterial tissue. Its half-life is approximately 62 hours, allowing it to diffuse readily into tissue and remain there long enough to exert a beneficial effect. During clinical trials, patients received up to six stents totaling $54 \mathrm{~mm}$ in length without untoward effects. Furthermore, doses six times greater than those used in clinical trials also exhibited no toxicity in 30-day animal studies. The dose response curve illustrates its broad safety window (see Figure 6). Normal re-endothelialization is a key factor in preventing thrombosis. Preclinical data for the Cypher stent showed complete re-endothelialization at 30 days, and this was demonstrated in clinical trials as well.

\section{Efficacy of drug-eluting stents}

Drug-eluting stents have been used extensively since the Cypher stent was first approved in 2003. The indications

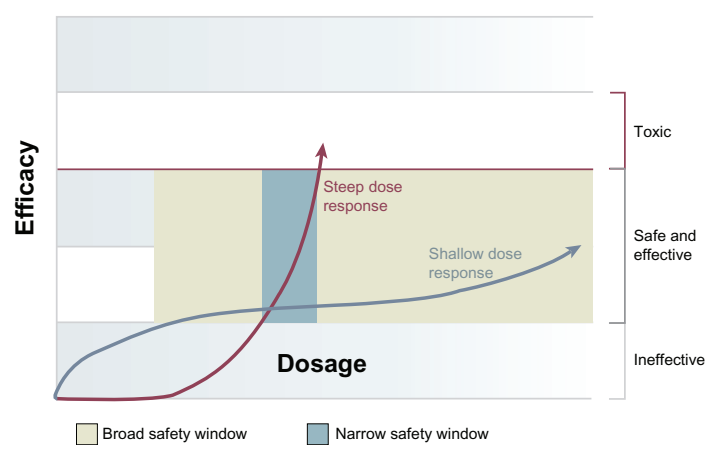

Figure 6 Dose-response curve for Cypher ${ }^{\circledR}$ stent.

Note: Drug-eluting stents versus bare metal stents for angina or acute coronary syndromes.

(C) Cordis Corporation 2010. for their use have expanded over the years. Traditionally approved (on-label) indications for using drug-eluting stents have included discrete, previously untreated lesions in native coronary vessels. These are the types of lesions that have been extensively studied in early clinical trials involving drug-eluting stents. Over time, these stents has also been used to treat complex coronary artery disease states, including left main lesions, multivessel coronary artery disease, acute myocardial infarction, bifurcation lesions, moderate to heavily calcified lesions, chronic total occlusions, and saphenous vein graft stenosis.

The sirolimus-eluting stent showed significant promise for the prevention of neointimal proliferation, restenosis, and major cardiovascular events in an early French study published in 2002. ${ }^{9}$ Numerous studies have unequivocally shown the effectiveness of drug-eluting stents in discrete single-vessel coronary lesions. Drug-eluting stents in ST segment elevation myocardial infarction (STEMI) patients have consistently been shown to decrease the risk of repeat revascularization, without increasing the incidence of stent thrombosis or recurrent myocardial infarction. ${ }^{10,11}$ However, a recent study concluded that drug-eluting stents used in STEMI have a higher rate of cardiac death not attributable to myocardial infarction or stent thrombosis. ${ }^{12}$ Drug-eluting stent use in STEMI also showed a significantly higher threeyear survival rate free from major adverse cardiovascular events and a lower rate of target vessel revascularization and target vessel failure when compared with bare-metal stents (Table 1). ${ }^{13}$ A similar result was obtained in another study, with benefits observed for up to four years. ${ }^{14}$ Similarly, Table 2 shows event rates for all stents at five years. A metaanalysis of 13 clinical trials comparing drug-eluting stents and bare-metal stents concluded that drug-eluting stents significantly reduced target vessel revascularization without

Table I Clinical outcome at three years

\begin{tabular}{llll}
\hline & SES group & BMS group & P value \\
\hline $\mathrm{n}$ & 157 & 156 & \\
Death & $5(3.2)(1-7.2)$ & $8(5)(2.2-10)$ & 0.38 \\
Reinfarction & $4(2.5)(0.7-6.3)$ & $4(2.5)(0.7-6.4)$ & NS \\
Stent thrombosis & & & \\
Definite & $3(1.9)(0.4-5.4)$ & $2(1.3)(0.1-4.5)$ & NS \\
Probable/possible & $5(3.2)(1-7.2)$ & $6(3.8)(1.4-8.1)$ & NS \\
MACE & $20(12.7)(8-18)$ & $33(21)(15-28)$ & 0.034 \\
TLR & $11(7)(3.5-12)$ & $21(13.5)(8.5-19)$ & 0.048 \\
TVR & $13(8.3)(4-13)$ & $25(16)(10-22)$ & 0.027 \\
TVF & $18(11.5)(7-17)$ & $32(20.5)(14-27)$ & 0.028 \\
\hline
\end{tabular}

Note: Values are $\mathrm{n}(\%)$ and ( $95 \%$ confidence interval).

Abbreviations: MACE, major adverse cardiovascular event; TLR, target lesion revascularization; TVF, target vessel failure; TVR, target vessel revascularization; NS, not significant. 
Table 2 All stents: event rate, outcome: 6 event rate at five years ${ }^{47}$

Review: Drug-eluting stents verses bare metal stents for angina or acute coronary syndromes

Comparison: 1 all stents: event rate

Outcome: 6 event rate: 5 years

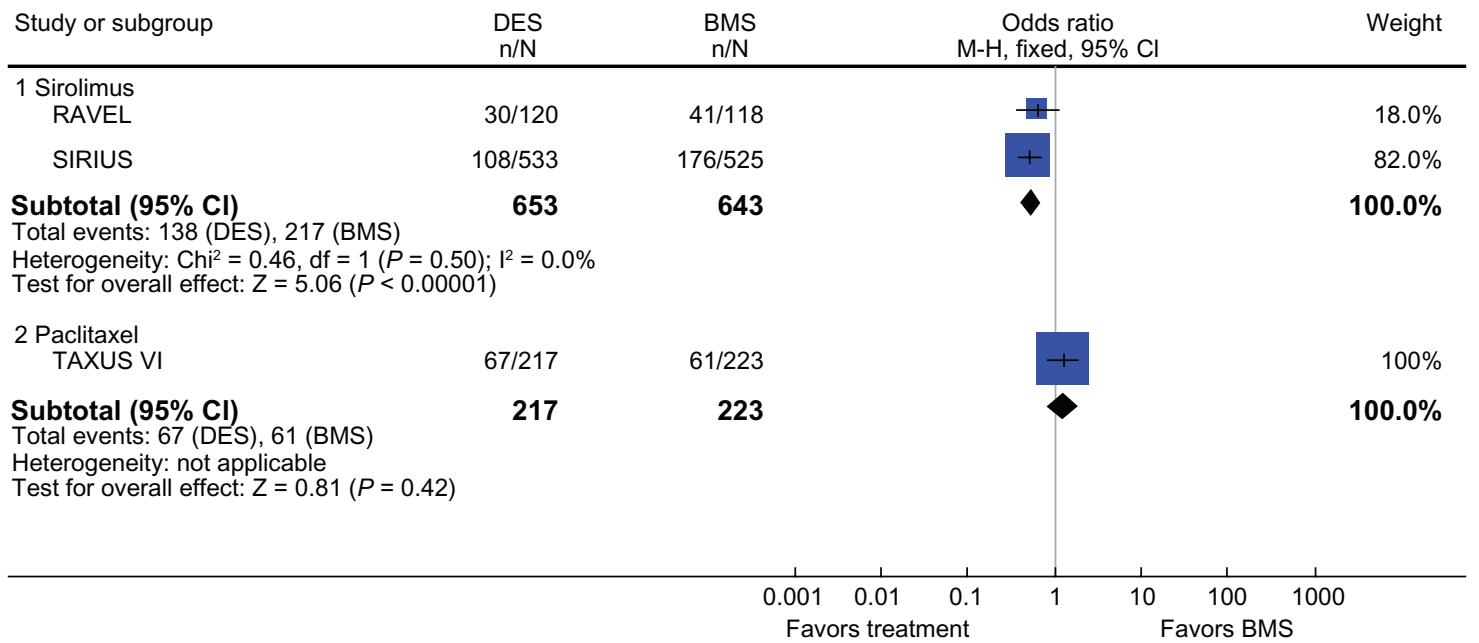

Table from Greenhalgh et al, Drug-eluting stents versus bare metal stents for angina or acute coronary syndromes, Cochrane Database Syst Rev, 20 I0, Vol I2, Issue 5, CD004587. Copyright Cochrane Collaboration, reproduced with permission.

Abbreviations: DES, Drug Eluting Stent; BMS, Bone Metal Stent; RAVEL, A Randomized Study with the sirolinus control Velocity balloon Expendable Stent; SIRIUS, Sirolinus-eluting stent.

increasing rates of thrombosis, death, or myocardial infarction.

The drug-eluting stent has been used in the treatment of unprotected left main coronary artery lesions. The drug-eluting stent was compared with coronary artery bypass grafting in the treatment of unprotected left main coronary artery lesions, and the conclusion was that the drug-eluting stent showed similar rates of mortality, but higher rates of target vessel revascularization when compared with coronary artery bypass grafting. ${ }^{15}$

The drug-eluting stent has been compared with coronary artery bypass grafting in the treatment of multivessel coronary artery disease in diabetic patients. There was no significant difference in rates of death and myocardial infarction between the two groups. Compared with coronary artery bypass grafting, the drug-eluting stent was associated with a higher risk of major cardiovascular events (odds ratio [OR] $0.18,95 \%$ confidence interval $[\mathrm{CI}] 0.11-0.30, P=0.30$ ) and a lower risk of cerebrovascular events (OR 2.15, 95\% CI $0.99-4.68, P=0.80) .{ }^{16}$ The Arterial Revascularization Therapies Study II compared the sirolimus-eluting stent, the bare-metal stent, and coronary artery bypass grafting in patients with de novo multivessel coronary artery disease. The percentage of percutaneous three-vessel treatment was $46.6 \%$ for the sirolimus-eluting stent versus $18.0 \%$ for the bare-metal stent $(P<0.001)$. The mean (standard deviation) number of significant lesions per patient was $3.6 \pm 1.3$ for the sirolimus-eluting stent versus $2.8 \pm 1.0$ for coronary artery bypass grafting $(P<0.001)$ and $2.8 \pm 1.0$ for bare-metal stents. Patients allocated to the sirolimus-eluting stent group received a mean of $3.7 \pm 1.5$ stents, with an average total stented length of $72 \pm 32 \mathrm{~mm}$, compared with $2.8 \pm 1.3$ stents and a stented length of $48 \pm 22 \mathrm{~mm}$ in bare-metal stented patients $(P<0.001)$. The conclusions of this study were that the drug-eluting stent was comparable with coronary artery bypass grafting and superior to bare-metal stents for reducing the risks of major adverse cardiovascular and cerebrovascular events. ${ }^{17}$ The SPIRIT-II trial tested everolimus-eluting stents in patients with calcified coronary artery lesions. This study concluded that the calcified group had higher instent restenosis and major adverse cardiovascular events rates when compared with the noncalcified group $(7.4 \%$ versus $0 \%, P=0.08){ }^{18}$ Drug-eluting stents were also studied in the treatment of very long segment diffuse de novo coronary artery lesions and were found to be effective in this subset as well. ${ }^{19}$ The mean follow-up duration in this study was 26.5 months.

Chronic total occlusions are another group of patients in whom the drug-eluting stent has been studied. In a metaanalysis involving 14 studies and more than 4000 patients, the drug-eluting stent was found to be more effective than bare-metal stents in reducing the risk of major adverse cardiovascular events (relative risk [RR] 0.45, 95\% CI 0.34-0.60, $P<0.001)$ and target vessel revascularization for up to three years (RR 0.40, 95\% CI 0.28-0.58, $P<0.001$ ). ${ }^{20}$

Finally, the drug-eluting stent has been studied in degenerative saphenous vein graft stenosis. A meta-analysis published in early 2010 of observational studies concluded 
that the drug-eluting stent used for vein graft stenosis needs larger multicenter, randomized, controlled trials to confirm its effectiveness and to address safety issues. ${ }^{21}$

\section{Safety issues with sirolimus}

Initial approval of the sirolimus-eluting stent was based on two randomized, controlled trials involving more than 1000 patients, each showing reduced rates of target vessel revascularization and target vessel failure when compared with bare-metal stents. Initial enthusiasm led to rapid acceptance of the use of the drug-eluting stent, and soon approximately $80 \%$ of all stents used in the US were drug-eluting stents. Safety concerns about the drug-eluting stent surfaced in 2006 when late thrombosis, death, and myocardial infarction were reported to be higher in patients receiving drug-eluting stents than in those receiving bare-metal stents. DESIRE (Drug-Eluting Stents in the Real World) was a prospective, nonrandomized, single-center registry trial ${ }^{22}$ that reported on the incidence and predictors of stent thrombosis and major adverse cardiovascular events. In this study, patients were followed up for a median period of five years. The incidence of stent thrombosis was $1.7 \%$ in this study (hazards ratio [HR] 3.02, 95\% CI 1.27-7.19, $P=0.012$ ). Multiple studies have reported an increased incidence of stent thrombosis and nonfatal myocardial infarction when drug-eluting stents are used for off-label indications..$^{22-24}$

The incidence of stent thrombosis within the first year was identical between sirolimus-eluting stents and baremetal stents, as well as between paclitaxel-eluting stents and bare-metal stents. No significant differences in the cumulative four-year rates of death or myocardial infarction were observed between the drug-eluting stent and bare-metal stent groups $(P=0.20) .{ }^{25}$ Between one and four years after stent implantation, the incidence of stent thrombosis was higher in the drug-eluting stent group than in the bare-metal stent group $(P=0.025){ }^{25,26}$

In another meta-analysis of randomized controlled trials and observational studies, no significant differences were observed in the long-term rates of myocardial infarction (HR $0.95,95 \%$ CI $0.79-1.13, P=0.54$ ) or death (HR 0.97, 95\% CI $0.81-1.15, P=0.72$ ) after drug-eluting stent or bare-metal stent use for either on-label or off-label indications, ${ }^{27}$ and the conclusion was that sirolimus is safe in both on-label and offlabel indications. Another comprehensive meta-analysis of 28 trials comparing drug-eluting stents with bare-metal stents reached the conclusions that there was no excess mortality with the drug-eluting stent $(5.9 \%$ versus $5.7 \%, P=0.79)$, that the drug-eluting stent appears to be safe and effective within one year, with possibly decreased rates of non- $Q$ wave myocardial infarction and significantly decreased target vessel revascularization $(P=0.001)$ compared with bare-metal stents, and similar mortality between the drug-eluting stent and bare-metal stent after one year, despite an increased rate of stent thrombosis $(0.7 \%$ versus $0.3 \%, P=0.006) .{ }^{28}$

In DESIRE, 2084 patients treated with the drug-eluting stent were followed for a mean duration of $2.6 \pm 1.2$ years. The results of this study showed a target vessel revascularization rate of $3.3 \%$, non-Q wave myocardial infarction $0.7 \%$, and stent thrombosis $1.6 \%$. This study concluded that use of the drug-eluting stent in an unselected population is associated with long-term safety and effectiveness, with acceptable low rates of clinically significant adverse events. ${ }^{29}$

\section{Comparison of various drug-eluting stents}

The first-generation drug-eluting stents are the sirolimuseluting (Cypher) stent and the paclitaxel-eluting (TAXUS ${ }^{\circledR}$ ) stent. The second-generation stents are the zotarolimuseluting (ENDEAVOR ${ }^{\circledR}$ ) stent and the everolimus-eluting $\left(\mathrm{XIENCE}^{\circledR}\right)$ stents.

The TAXUS IV trial compared the paclitaxel-eluting stent with the bare-metal stent in single-vessel de novo coronary lesions. The paclitaxel-eluting stent showed better long-term efficacy with regard to target vessel revascularization at five years $(27.4 \%$ versus $16.9 \%, P<0.0001)$ and safety with regard to major adverse cardiovascular events at five years ( $24 \%$ versus $32.8 \%, P=0.001)$ and stent thrombosis at five years $(2.2 \%$ versus $2.1 \%, P=0.87) .{ }^{30}$

The ENDEAVOR II trial compared the zotarolimuseluting stent and the bare-metal stent over a four-year follow-up period. The zotarolimus-eluting stent was shown to be effective in reducing target vessel revascularization (10.4\% versus $21.5 \%, P<0.001)$ during four years of follow-up without any significant difference in rates of death $(5 \%$ versus $5.2 \%, P=0.29)$ or nonfatal myocardial infarction $(3.2 \%$ versus $4.4 \%, P=0.29) .{ }^{31}$ Multiple studies comparing various drug-eluting stents with bare-metal stents have reached similar conclusions as the above studies. $^{32,33}$

All the four drug-eluting stents have definitely proved superior to bare-metal stents in head-to-head studies. In a meta-analysis of 14 trials comparing the sirolimus-eluting stent with the bare-metal stent, use of the sirolimus-eluting stent did not have a significant effect on overall long-term survival free of myocardial infarction when compared with the bare-metal stent $(P=0.56)$. However, there was a significant reduction in need for reintervention after use of the sirolimus-eluting stent. There was evidence of a slight increase in overall risk of stent 
thrombosis with the sirolimus-eluting stent when compared with the bare-metal stent after the first year $(P=0.49) .{ }^{34}$

The SORT-OUT III trial compared the sirolimus-eluting stent with the zotarolimus-eluting stent, and concluded that the sirolimus-eluting stent was superior to the zotarolimuseluting stent for patients receiving routine clinical care (major adverse cardiovascular events $3 \%$ versus $6 \%, P=0.0002$ ) and for all-cause mortality ( $4 \%$ versus $3 \%, P=0.035) .{ }^{35}$ The ENDEAVOR IV trial compared the zotarolimus-eluting stent and the paclitaxel-eluting stent. The conclusions of this study were that the zotarolimus-eluting stent has similar clinical safety and efficacy to the paclitaxel-eluting stent (target vessel failure $6.6 \%$ versus $7.1 \%$, respectively, target vessel revascularization at 12 months $4.5 \%$ versus $3.2 \%, P=0.228$ ) in simple and medium complexity single de novo coronary lesions.

A single-center registry study from Singapore evaluated the safety and efficacy of the sirolimus-eluting, paclitaxel-eluting, and zotarolimus-eluting stents in diabetic patients with complex coronary lesions. At 18 months, the rates of major adverse cardiovascular events were $12.7 \%, 8.7 \%$, and $12.7 \%$, respectively. Stent thrombosis was found in one patient each in the sirolimus-eluting stent and zotarolimus-eluting stent groups and in two patients in the paclitaxel-eluting stent group. The conclusion was that there was no significant difference in efficacy between the three stent groups $(P=0.228) .{ }^{36}$ The zotarolimus-eluting stent was compared with the everolimuseluting stent in a recently published study with a follow-up duration of 13 months. The conclusions of the study were that the zotarolimus-eluting stent was noninferior to the everolimus-eluting stent with regard to major adverse cardiovascular events $(8.2 \%$ versus $8.3 \%)$ and stent thrombosis ( $2.3 \%$ versus $1.5 \%, P<0.001$ for noninferiority). ${ }^{37}$

In a prospective, multicenter German drug-eluting stent registry, the sirolimus-eluting stent was compared with the paclitaxel-eluting stent in diabetic patients. Target vessel revascularization was achieved in $12 \%$ versus $11.3 \%$. The rate of major adverse cardiovascular events was $11.4 \%$ versus 10.3 and the rate of stent thrombosis was $5.6 \%$ versus $4.6 \%$. It was concluded that the sirolimus-eluting and paclitaxeleluting stents were similar with regard to outcome in diabetics $(P<0.05) .{ }^{38}$ The everolimus-eluting stent and the paclitaxeleluting stent were compared in the SPIRIT II and III trials. The conclusion was that the everolimus-eluting stent was superior to the paclitaxel-eluting stent in patients with small coronary vessel disease, with major adverse cardiovascular event rates of $5.2 \%$ versus $10.7 \%, P=0.037 .^{39}$

Patients who have received the sirolimus-eluting stent have shown better clinical outcomes than those who have received the paclitaxel-eluting stent. ${ }^{26,40-42}$ In one study, two-dimensional intravascular ultrasound showed an overall intimal hyperplasia rate of $2.8 \%$ with the sirolimus-eluting stent versus $13.8 \%$ for the paclitaxel-eluting stent. ${ }^{43,44}$ In another study, the sirolimus-eluting stent were compared with the paclitaxel-eluting stent, and after 24 months of follow-up, patients who received the paclitaxel-eluting stent had significantly higher rates of non-Q wave myocardial infarction $(5.9 \%$ versus $1.9 \%, P=0.002)$, target vessel revascularization $(4.9 \%$ versus $1.9 \%, P=0.002)$, and coronary artery bypass graft surgery $(6.9 \%$ versus $1.9 \%$, $P=0.002$ ).

In a meta-analysis of randomized trials, the sirolimuseluting stent was compared with the paclitaxel-eluting stent in patients who had suffered a STEMI. It was found that the sirolimus-eluting stent was superior to the paclitaxeleluting stent for reducing the incidence of restenosis $(4 \%$ versus $9.6 \%, P=0.004$ ) in patients undergoing primary percutaneous coronary intervention for STEMI, without any significant differences in death, myocardial infarction, target vessel revascularization, or stent thrombosis. ${ }^{45}$ However, the deliverability of the sirolimus-eluting stent in tortuous and calcified vessels remains more difficult than with the paclitaxel-eluting and zotarolimus-eluting stents.

\section{Patient satisfaction}

Patient satisfaction is always directly proportional to the least number of interventions needed to make them feel better. During this era of the Internet, many patients and/or their relatives have access to the results of the clinical trials described here. In the light of current knowledge, a longer-lasting stent, ie, the sirolimus-eluting stent, generates more confidence in the patient as well as in the physician performing the procedure.

\section{Future advances}

While there are good clinical data for the drug-eluting stent, several safer drug-eluting stents with biodegradable polymers are available commercially in Europe. These include the SUPRALIMUS ${ }^{\circledR}$ stent, the EXCEL ${ }^{\circledR}$ stent, and the $\mathrm{NEVO}^{\circledR}$ stent, with several others presently undergoing clinical investigation. Interest has focused on these stents because after implantation, in theory they may offer the initial antirestenotic benefits of a standard drug-eluting stent, as well as the safety benefits of the bare-metal stent after the polymer has biodegraded. The important remaining question is whether this new technology will lead to improved clinical outcomes. Unfortunately, present studies of these stents are limited by short-term follow-up. 
The NEVO stent is well studied compared with the others, but has only been evaluated in the NEVO RES-ELUTION study, which was a randomized, multicenter, noninferiority study comparing the NEVO stent with the TAXUS Liberté ${ }^{\circledR}$ paclitaxel-eluting stent in 394 patients with single de novo coronary artery lesions. At six-month angiographic follow-up, the primary endpoint of instent late lumen loss was significantly lower in patients treated with the NEVO stent. Future trials of this promising stent technology are planned for 2011. In particular, the NEVO II study has commenced, and will randomize 2500 "all-comers" to treatment with either the NEVO stent or the Xience $\mathrm{V}^{\circledR}$ everolimus-eluting stent, with clinical follow-up planned annually out to five years. ${ }^{46}$

\section{Conclusion}

There would be very few areas in modern medicine that have generated as much debate as coronary drug-eluting stent implantation. Evidence for the efficacy of drugeluting stents in reducing clinical restenosis is consistent. In our interpretation of the available data, we conclude that the benefit of drug-eluting stent therapy when compared with the bare-metal stents in reducing restenosis is of the order of $35 \%-70 \%$, and is seen across a broad spectrum of lesions, encompassing both on-label and off-label indications.

Percutaneous coronary intervention by its very nature produces severe coronary endothelial injury and an increased risk of thrombosis. After stent placement, platelet activation is usually reduced by the use of two platelet inhibitors with differing modes of action (aspirin and clopidogrel). The selection criteria for dual antiplatelet therapy is for future review, because there have been concerns regarding a higher risk of thrombotic occlusion and patient mortality in the short to medium term. These complications following sirolimus implantation have not been fully studied by systematic data analysis. Analysis of the available benefit and risk data has shown that drug-eluting stent implantation should be the preferred approach for treating patients with obstructive coronary disease and who require percutaneous coronary intervention. The sirolimus-eluting stent has been shown to be safe and effective in percutaneous coronary intervention since 2003. Many studies have published long-term safety data, and these devices have proven to be valuable assets in treating coronary artery disease. It is clear that no single stent design and polymer type will be suitable for all patients and lesion types. Therefore, a more individualized choice of stent should take into account individual patient characteristics.

\section{Disclosure}

The authors report no conflicts of interest in this work.

\section{References}

1. Grüntzig AR, Senning A, Siegenthaler WE. Nonoperative dilatation of coronary-artery stenosis: Percutaneous transluminal coronary angioplasty. N Engl J Med. 1979;301(2):61-68.

2. Dotter CT, Judkins MP. Transluminal treatment of arteriosclerotic obstruction. Circulation. 1964;30(5):654-670.

3. Serruys PW, Kutryk MJ, Ong AT. Coronary artery stents. $N$ Engl $J$ Med. 2006;354(5):483-495.

4. Angioplasty.org [homepage on the Internet]. 1996-2011. [updated 2011 April 6]. Available from http://www.angioplasty.org/. Accessed April 6, 2011.

5. Endo A, Hirayama H, Yoshida O, et al. Arterial remodeling influences the development of intimal hyperplasia after stent implantation. $J$ Am Coll Cardiol. 2001;37(1):70-75.

6. Hoffmann R, Mintz GS. Coronary in-stent restenosis - predictors, treatment and prevention. Eur Heart J. 2000;21(21):1739-1749.

7. Mintz GS, Tinana A, Hong MK, et al. Impact of preinterventional arterial remodeling on neointimal hyperplasia after implantation of (non-polymer encapsulated) paclitaxel-coated stents: A serial volumetric intravascular ultrasound analysis from the ASian PaclitaxelEluting Stent Clinical Trial (ASPECT). Circulation. 2003;108(11): $1295-1298$.

8. Kang WC, Oh KJ, Han SH, et al. Effect of preinterventional arterial remodeling on intimal hyperplasia after implantation of a polymer-based paclitaxel-eluting stent: Angiographic and IVUS study. Int $J$ Cardiol. 2007;123(1):50-54.

9. Morice MC, Serruys PW, Sousa JE, et al; RAVEL Study Group. A randomized comparison of a sirolimus-eluting stent with a standard stent for coronary revascularization. $N$ Engl J Med. 2002;346(23): 1773-1780.

10. Nakagawa Y. What is the effectiveness of drug-eluting stents in the treatment of ST-elevation myocardial infarction? - should drug-eluting stents be indicated for patients with acute coronary syndrome? Circ J. 2010;74(10):2225-2231.

11. Dibra A, Tiroch K, Schulz S, et al. Drug-eluting stents in acute myocardial infarction: Updated meta-analysis of randomized trials. Clin Res Cardiol. 2010;99(6):345-357.

12. Kaltoft A, Kelbaek H, Thuesen L, et al. Long-term outcome after drugeluting versus bare-metal stent implantation in patients with ST-segment elevation myocardial infarction: 3-year follow-up of the randomized DEDICATION (Drug Elution and Distal Protection in Acute Myocardial Infarction) Trial. J Am Coll Cardiol. 2010;56(8):641-645.

13. Violini R, Musto C, De Felice F, et al. Maintenance of long-term clinical benefit with sirolimus-eluting stents in patients with ST-segment elevation myocardial infarction 3-year results of the SESAMI (sirolimuseluting stent versus bare-metal stent in acute myocardial infarction) trial. J Am Coll Cardiol. 2010;55(8):810-814.

14. Di Lorenzo E, Sauro R, Varricchio A, et al. Benefits of drug-eluting stents as compared to bare metal stent in ST-segment elevation myocardial infarction: Four year results of the PaclitAxel or Sirolimus-Eluting stent vs bare metal stent in primary angioplasty (PASEO) randomized trial. Am Heart J. 2009;158(4):e43-e50.

15. Park DW, Seung KB, Kim YH, et al. Long-term safety and efficacy of stenting versus coronary artery bypass grafting for unprotected left main coronary artery disease: 5-year results from the MAIN-COMPARE (Revascularization for Unprotected Left Main Coronary Artery Stenosis: Comparison of Percutaneous Coronary Angioplasty Versus Surgical Revascularization) registry. J Am Coll Cardiol. 2010;56(2):117-124.

16. Lee MS, Yang T, Dhoot J, Iqbal Z, Liao H. Meta-analysis of studies comparing coronary artery bypass grafting with drug-eluting stenting in patients with diabetes mellitus and multivessel coronary artery disease. Am J Cardiol. 2010;105(11):1540-1544. 
17. Serruys PW, Onuma Y, Garg S, et al; ARTS II Investigators. 5-year clinical outcomes of the ARTS II (Arterial Revascularization Therapies Study II) of the sirolimus-eluting stent in the treatment of patients with multivessel de novo coronary artery lesions. $\mathrm{J} \mathrm{Am} \mathrm{Coll} \mathrm{Cardiol.}$ 2010;55(11):1093-1101.

18. Onuma Y, Tanimoto S, Ruygrok P, et al. Efficacy of everolimus eluting stent implantation in patients with calcified coronary culprit lesions: Two-year angiographic and three-year clinical results from the SPIRIT II study. Catheter Cardiovasc Interv. 2010;76(5):634-642.

19. Andron M, Ramsdale DR, Rao A, Ramsdale KA, Albouaini K. Clinical outcomes after percutaneous coronary intervention involving very long segments of drug-eluting stent implantation: Single-center experience. J Invasive Cardiol. 2009;21(2):46-50.

20. Colmenarez HJ, Escaned J, Fernández C, et al. Efficacy and safety of drug-eluting stents in chronic total coronary occlusion recanalization: A systematic review and meta-analysis. $J$ Am Coll Cardiol. 2010;55(17):1854-1866.

21. Joyal D, Filion KB, Eisenberg MJ. Effectiveness and safety of drug-eluting stents in vein grafts: A meta-analysis. Am Heart J. 2010;159(2):159-169.e4.

22. Costa JR Jr, Sousa A, Moreira AC, et al. Incidence and predictors of very late ( $>$ or $=4$ years) major cardiac adverse events in the DESIRE (Drug-Eluting Stents in the Real World)-Late registry. JACC Cardiovasc Interv. 2010;3(1):12-18.

23. Maisel WH. Unanswered questions - drug-eluting stents and the risk of late thrombosis. $N$ Engl J Med. 2007;356(10):981-984.

24. Beattie MJ, Lee MS. Safety and efficacy of drug-eluting stents compared with bare metal stents in ST-elevation myocardial infarction. Rev Cardiovasc Med. 2010;11(2):57-73.

25. Stone GW, Moses JW, Ellis SG, et al. Safety and efficacy of sirolimus- and paclitaxel-eluting coronary stents. N Engl J Med. 2007;356(10): 998-1008.

26. Mauri L, Hsieh WH, Massaro JM, Ho KK, D’Agostino R, Cutlip DE. Stent thrombosis in randomized clinical trials of drug-eluting stents. N Engl J Med. 2007;356(10):1020-1029.

27. Kirtane AJ, Gupta A, Iyengar S, et al. Safety and efficacy of drug-eluting and bare metal stents: Comprehensive meta-analysis of randomized trials and observational studies. Circulation. 2009;119(25):3198-3206.

28. Roukoz H, Bavry AA, Sarkees ML, et al. Comprehensive meta-analysis on drug-eluting stents versus bare-metal stents during extended follow-up. Am J Med. 2009;122(6):581.e1-e10.

29. Sousa A, Costa JR Jr, Moreira AC, et al. Long-term clinical outcomes of the Drug-Eluting Stents in the Real World (DESIRE) Registry. J Interv Cardiol. 2008;21(4):307-314.

30. Ellis SG, Stone GW, Cox DA, et al; TAXUS IV Investigators. Long-term safety and efficacy with paclitaxel-eluting stents: 5-year final results of the TAXUS IV clinical trial (TAXUS IV-SR: Treatment of De Novo Coronary Disease Using a Single Paclitaxel-Eluting Stent). JACC Cardiovasc Interv. 2009;2(12):1248-1259.

31. Eisenstein EL, Leon MB, Kandzari DE, et al; ENDEAVOR III Investigators Long-term clinical and economic analysis of the Endeavor zotarolimuseluting stent versus the Cypher sirolimus-eluting stent: 3-year results from the ENDEAVOR III trial (Randomized Controlled Trial of the Medtronic Endeavor Drug [ABT-578] Eluting Coronary Stent System Versus the Cypher Sirolimus-Eluting Coronary Stent System in De Novo Native Coronary Artery Lesions). JACC Cardiovasc Interv. 2009;2(12):1199-1207.

32. Applegate RJ, Sacrinty MT, Kutcher MA, Santos RM, Gandhi SK, Little WC. 3-year comparison of drug-eluting versus bare-metal stents. JACC Cardiovasc Interv. 2009;2(3):231-239.

Medical Devices: Evidence and Research

\section{Publish your work in this journal}

Medical Devices: Evidence and Research is an international, peerreviewed, open access journal that focuses on the evidence, technology, research, and expert opinion supporting the use and application of medical devices in the diagnosis, treatment and management of clinical conditions and physiological processes. The identification of novel
33. Auer J, Leitner A, Berent R, Lamm G, Lassnig E, Krennmair G. Long-term outcomes following coronary drug-eluting- and baremetal-stent implantation. Atherosclerosis. 2010;210(2):503-509.

34. Kastrati A, Mehilli J, Pache J, et al. Analysis of 14 trials comparing sirolimus-eluting stents with bare-metal stents. $N$ Engl J Med. 2007; 356(10):1030-1039.

35. Rasmussen K, Maeng M, Kaltoft A, et al. SORT OUT III study group. Efficacy and safety of zotarolimus-eluting and sirolimus-eluting coronary stents in routine clinical care (SORT OUT III): A randomized controlled superiority trial. Lancet. 2010;375(9720):1090-1099.

36. Leon MB, Mauri L, Popma JJ, et al. ENDEAVOR IV Investigators. A randomized comparison of the ENDEAVOR zotarolimus-eluting stent versus the TAXUS paclitaxel-eluting stent in de novo native coronary lesions 12-month outcomes from the ENDEAVOR IV trial. J Am Coll Cardiol. 2010;55(6):543-554.

37. Serruys PW, Silber S, Garg S, et al. Comparison of zotarolimus-eluting and everolimus-eluting coronary stents. $N$ Engl J Med. 2010;363(2): 136-146.

38. Akin I, Bufe A, Eckardt L, et al; DES Study Group. Outcomes after differential use of drug-eluting stents in diabetic patients: 1-year results from the DES. DE (Drug-Eluting Stent.DEutschland) registry. Catheter Cardiovasc Interv. 2010;76(1):50-57.

39. Camenzind E, Steg PG, Wijns W. Stent thrombosis late after implantation of first-generation drug-eluting stents: A cause for concern. Circulation. 2007;115(11):1440-1455.

40. Pfisterer M, Brunner-La Rocca H, Buser PT, et al. for the BASKETLATE Investigators. Late clinical events after clopidogrel discontinuation may limit the benefit of drug-eluting stents: An observational study of drugeluting versus bare-metal stents. J Am Coll Cardiol. 2006;48(12):2584-2591.

41. Ciçek D, Pekdemir H, Kalay N, Binici S, Altay H, Müderrisoğlu H. Efficacy of sirolimus-eluting stents compared with paclitaxel eluting stents in an unselected population with coronary artery disease: 24 month outcome of patients in a prospective non-randomized registory in southern Turkey. Int J Med Sci. 2010:7(4):191-196.

42. Serruys PW, Degertekin M, Tanabe K, et al. Intravascular ultrasound findings in the multicenter, randomized, double-blind RAVEL (Randomized study with the sirolimus-eluting VElocity balloon-expandable stent in the treatment of patients with de novo native coronary artery Lesions) trial. Circulation. 2002;106(7):798-803.

43. Sonoda S, Morino Y, Ako J, et al. SIRIUS Investigators. Impact of final stent dimensions on long term results following sirolimus-eluting stent implantation: serial intravascular ultrasound analysis from the serial trial. J Am Coll Cardiol. 2004;43(11):1959-1963.

44. Bartorelli AL, Serruys PW, Miquel-Hébert K, Yu S, Pierson W, Stone GW. SPIRIT II SPIRIT III Investigators. An everolimus-eluting stent versus a paclitaxel-eluting stent in small vessel coronary artery disease: A pooled analysis from the SPIRIT II and SPIRIT III trials. Catheter Cardiovasc Interv. 2010;76(1):60-66.

45. Li YL, Wan Z, Lu WL, Wang JH. Comparison of sirolimus- and paclitaxel-eluting stents in patients undergoing primary percutaneous coronary intervention for ST-elevation myocardial infarction: A metaanalysis of randomized trials. Clin Cardiol. 2010;33(9):583-590.

46. Garg S, Serruys PW. Coronary stents: Looking forward. J Am Coll Cardiol. 2010;56(10 Suppl):S43-S78.

47. Greenhalgh J, Hockenhull J, Rao N, Dundar Y, Dickson RC, Bagust A. Drug-eluting stents versus bare metal stents for angina or acute coronary syndromes. Cochrane Database Syst Rev. 2010;(5):CD004587.

\section{Dovepress}

devices and optimal use of existing devices which will lead to improved clinical outcomes and more effective patient management and safety is a key feature. The manuscript management system is completely online and includes a quick and fair peer-review system. Visit http://www. dovepress.com/testimonials.php to read real quotes from authors. 